$$
\begin{aligned}
& \text { 流水によるファイバースコープ洗浄器の検討 } \\
& \text { 板橋 隆嗣 - 中川 利香 - 江渡 篤子* } \\
& \text { 桜井 淳* } \cdot \text { 山川 卓也* } \\
& \text { 古川 朋靖* }
\end{aligned}
$$

\title{
Bacteriological Study on a New Washer with Running Water for Fiberoptic Endoscopes
}

\author{
Takatsugu Itabashi and Rika Nakagawa \\ (Koto Hospital)
}

\begin{abstract}
Atsuko Eto, Atsushi Sakurai, Takuya Yamakawa, Masaharu Ishikawa and Tomoyasu Furukawa

(Juntendo University)
\end{abstract}

Sterilization of the flexible laryngeal fiberscope was tested with a newly designed washer which uses running water. Its efficacy was studied in 102 patients undergoing endoscopic examinations.

The main part of the washer was a cloro-vinyl pipe $16 \mathrm{~mm}$ in diameter, into which the fiberscope was inserted, and fresh water was kept flowing for 3 minutes. Statistically, 1.65 strains of bacteria were detected at the tip of the endoscopes immediately after endoscopic examinations.

The incidence of the cases which all strains of bacteria detected before washing were disappeared was $83.3 \%$, and the non effective cases by washing were $9.8 \%$. The cases were $24.5 \%$ which a few new strains of bacteria never detected pre-washing were appeared postwashing. These strains of bacteria detected after washing were small in quantity and revealed pathologically low grade. The tips of the nasal endoscopes used in patients with epistaxis all had negative occult blood tests after washing for 5 minutes.

The use of the washer was considered to be clinicaly effective in the occasion of the continuous endoscopy.

Key words: fideroptic endoscope, washer with running water, bacteriological study

\section{はじめに}

咽喉頭ファイバースコープは，日常の耳鼻科 外来診療に欠くべからざるものになって拉り, 使用頻度の高い施設も多いと思われる。しかる
に病的な鼻, 咽, 喉頭を観察し, 細菌が付着し ていることが考兄れるにもかかわらず，消毒 が充分行なえないまま，つぎつぎと患者に使用 してしまらことが多いのが実情であろう。 
当施設では咽喉頭ファイバースコープ使用後 はアルコール綿で挿入部分を清拭していたが， 先端に向かってアルコール綿でしごくために， 先端に挿入部分の外側コーティングがよってし まい，経鼻的に插入しにくい状態が生じた，又， 消毒用アルコールは，ファイバースコープ表面 の材質をいためるとも言われている。実際，当 施設使用のファイバースユープも，アルコール 綿で数多く清拭したものは黒色の表面の材質が 白色がかり，平滑でなくなってしまっている.

そこでこのようなファイバースュープの損傷 を来さず，かつ外来診療中に手軽にファイバー スコープを洗浄する方法が必要と思われた. 当 施設ではこれらの目的に合致するファイバース コープの流水洗浄器を考案試作し，その洗浄効 果を検討したので報告する。

\section{方法}

対象：江東病院耳鼻咽喉科外来に执いて咽喉 頭ファイバースコープ ENT30S II (町田製作所 製）を使用し, 鼻内, 上咽頭, 喉頭, 中・下咽
頭, 頸部食道の観察を行なった症例のなかで, 観察直後にファイバースコープ先端の細菌検索 を行ない, さらに洗浄器にて洗浄後直ちに先端 の細菌検索を同様に行ない得た102例について 検討した。明らかに菌が付着したままファイ バースコープ検查を行なった例を除く為に, こ れらの例についてはその直前の検討例でファイ バースコープ検査直後に検出された菌が洗浄後 も消失しなかった場合を除外してある。

またとの他にB型肝炎ウイルスやエイズウイ ルスの消毒効果の参考として，10例の鼻出血患 者について出血部位の確認に用いたファイバー スコープを洗浄し, 潜血反応を検討した.

洗浄器について: 水道用配管部品を組又合わ せ，図 1 に示したものを試作した.ファイバー スコープを挿入する部分の内径は $16 \mathrm{~mm}$ であ る. 洗浄器を上水道に接続し, 通水は洗浄管の 上端から水が溢れ出す流量まで水道栓を開いて 行なった．水はファイバースコープの挿入部分 にとって流れ，先端部分で直角に曲がることに
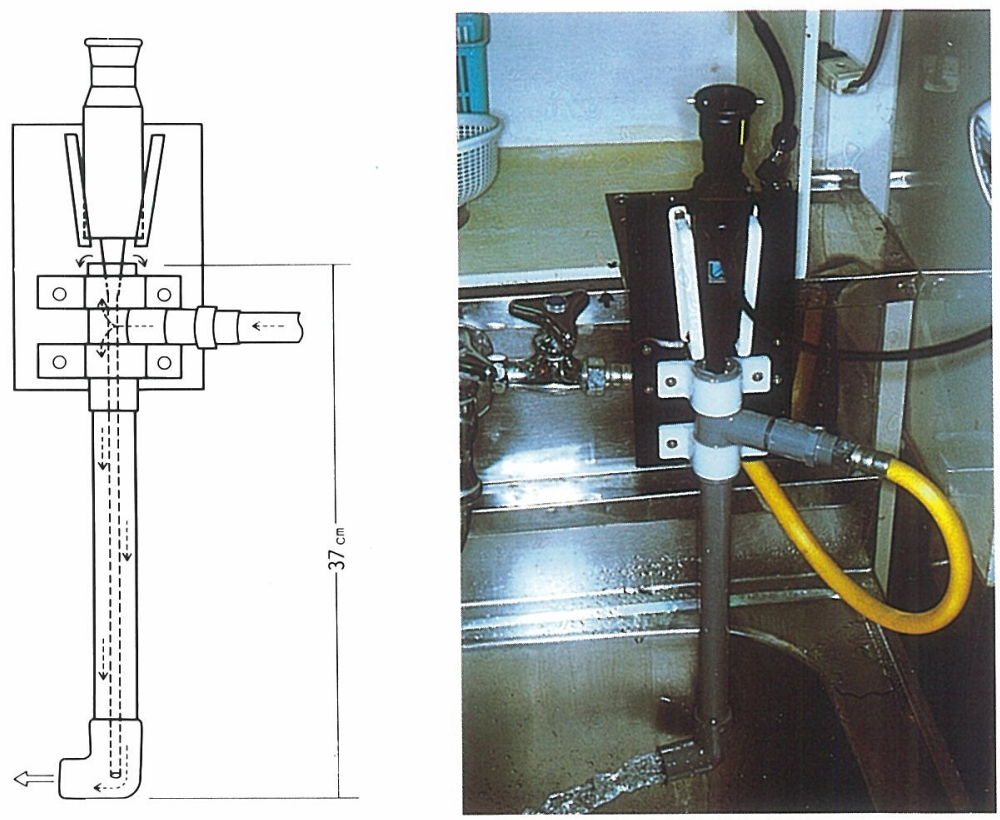

図 1 流水によるファイバースコープ洗浄器 
より先端の面を洗い流すように工夫した。洗浄 時間は 3 分とした. 洗浄管は週 1 回, 排出口に 栓をして管内に50倍ミルトンを満たし，30分放 置することにより消毒を行なった。 また，翌日 の始業前に管内壁から細菌検索を行ない，無菌 であることを確認した。

細菌検索について：ファイバースコープ先端 約 $1 \mathrm{~cm}$ を，試験管中の TCS 培地に浸して振 盪したものを洗浄前検体とし，洗浄器にて洗浄 を行なった直後，同様にして得た検体を洗浄後 検体とした，検体は東京総合臨床センタ一研究 部に提出し，報告を受けた。菌量の表現方法は コロニ一数を用い， $1+を 1 \sim 9 コ ロ=-， 2$ 十を10〜999コロニー，3+を1000コロニー以上 とした。

潜血反応について：鼻出血患者の出血部位の 確認にファイバースコープを用い，肉眼的に先 端付近に血液が付着したことを確認したらえで 洗浄を行なった． 3 分間の洗浄直後にファイ バースコープ先端に付着している水滴をエーム ス尿検査試験紙(マイルス三共製)の潜血反応試 験部分に付着させ，結果を判定した．結果が陰 性とならなかった例についてはさらに 1 分間ず つの洗浄を追加し，その度潜血反応を調べた。

\section{結果}

ファイバースコープの使用直後(以下洗浄前 と記すこととする) と, 洗浄器にて洗浄直後 (以 下洗浄後とする) との両方の細菌検索を行ない 得た102例から検出された細菌の一覧を表 1 に 示した。

洗浄前では39菌種168株が検出され, 最も多 く認められた菌種はCNS (Coagrase-negative staphylococci) 50 株，続いてS. aureus. 25株で あった. P. aeruginosa も 4 株認められた. 尚, 臨床上問題となる $\beta$-lactamase を産生する菌は 168株中76株 $45.2 \%$ に達した。一方, 検出され た細菌の菌量は 168 株中148株までが 1 十であっ た。

洗浄後には12菌種42株が検出された。最も多 く検出された菌種はCNS であり20株であった。
表 2 は検討し得た 102 例の検出株の菌数, 洗 浄効果, 残存菌種拈よびその菌量, 污染による 検出菌種およびその菌量を示したものである. 洗浄効果は洗浄前に検出された細菌のすべてが 消失した場合を菌消失とし，Aで表した。洗浄 前に検出された菌種の一部が残存した場合を菌 種減とし，Bで表した。 また菌種に関係なく洗

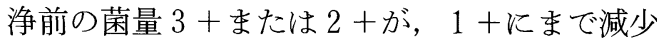
したものを菌量減とし，Cで表した。洗浄前と 洗浄後に菌種, 菌量とも変化が無かったものは 不変とし，Dで表した。洗浄前に細菌が認めら れなかった例はなく, 平均1.65種の細菌が検出 された。

表 3 に示すよらに, 洗浄前に検出された細菌 がすべて消失した例 (A)は85例(83.3\%)であり, 洗浄前 $P$. aeruginosa の検出された 4 例もすべ て菌消失 $(\mathrm{A})$ であった。菌種減 (B) は 6 例 (5.9 $\%)$, 菌量減 (C)は 1 例 $(1.0 \%)$ ，不変 $(\mathrm{D})$ は 10 例 $(9.8 \%)$ であった。これら計17例の残存菌名 は表 4 亿一括して示した．残存菌で最も多く認 められたのは，洗浄前の細菌検索でも最も多く 認められたCNS 7 例とS. aureus 6 例であっ た。 また残存菌量はすべて 1 +であった.

洗浄前に認められなかった菌種が洗浄後に検 出された例は25例 $(24.5 \%)$ となった。この25例 の菌名は表 5 に示した. CNS が13例と多く, 続いて Corynebacterium sp. が 4 例認められた.

な敃菌量が $3+$ から $2+$ になるど，洗浄後 の結果が上記 $\mathrm{A} \sim \mathrm{D}$ 以外になった例は認められ なかった。

鼻出血患者を観察したファイバースコープを 洗浄し，潜血反応を検討すると，表 6 に示すよ らに通常の 3 分間洗浄では 10 例中 2 例が反応陰 性となった. 残りの 8 例中 7 例は 1 分間の洗浄 を追加することにより反応陰性となり，1例は さらに 1 分間の洗浄を追加し, 計 5 分間の洗浄 を行らことにより反応陰性となった。すなわち 当施設で開発した洗浄器では，5 分間の洗浄を 行ならことによりファイバースコープ先端の潜 血反応は陰性となった。 
表 1 検出菌一覧

（ ）内の数字は洗浄後の菌株数を示す

\begin{tabular}{|c|c|c|c|c|c|}
\hline \multirow{2}{*}{ 分 離·固 定 菌 種 } & \multirow{2}{*}{$\beta$-lactamase } & \multicolumn{2}{|c|}{ 検 } & 株 & 数 \\
\hline & & $1+$ & $2+$ & $3+$ & 計 \\
\hline \multirow{2}{*}{ Staphylococcus aureus } & + & $18(5)$ & & 3 & $21(5)$ \\
\hline & - & $3(1)$ & & $1(1)$ & $4(2)$ \\
\hline \multirow{2}{*}{$C N S^{* 1}$} & - & $21(12)$ & & 1 & $22(12)$ \\
\hline & + & $26(8)$ & & 2 & $28(8)$ \\
\hline Streptococcus pyogenes & - & 1 & 1 & & 2 \\
\hline Streptococcus agalactiae & - & 4 & & & 4 \\
\hline Streptococcus gloup $G$ & - & 1 & & & 1 \\
\hline Streptococcus pneumoniae & - & $6(1)$ & & & $6(1)$ \\
\hline Streptococcus sanguis & - & $15(1)$ & & 3 & $18(1)$ \\
\hline Streptococcus mitis & - & 3 & & & 3 \\
\hline Streptococcus salivarius & - & 2 & & & 2 \\
\hline Streptococcus equinus & - & $2(2)$ & & & $2(2)$ \\
\hline Streptococcus bovis II & - & 3 & & & 3 \\
\hline Streptococcus sp. & - & $8(3)$ & 1 & 1 & $10(3)$ \\
\hline Enterococcus faecalis & - & 3 & & & 3 \\
\hline Corynebacterium sp. & - & $(4)$ & & & $(4)$ \\
\hline Bacillus subtilis & - & $1(2)$ & & & $1(2)$ \\
\hline Haemophilus influenzae & - & 1 & & & 1 \\
\hline Haemophilus parahaemolyticus & + & 1 & & & 1 \\
\hline Branhamella catarrhalis & + & 1 & 2 & & 3 \\
\hline Escherichia coli & - & 2 & & & 2 \\
\hline \multirow{2}{*}{ Klebsiella pneumoniae ${ }^{* 2}$} & + & 5 & & 2 & 7 \\
\hline & - & 1 & & 1 & 2 \\
\hline Klebsiella oxytoca & + & 3 & & & 3 \\
\hline \multirow{2}{*}{ Enterobacter aerogenes } & + & 3 & & & 3 \\
\hline & - & 1 & & & 1 \\
\hline Enterobacter cloacae & + & 1 & & & 1 \\
\hline Enterobacter gergoviae & - & 1 & & & 1 \\
\hline Enterobacter agglomerans & + & 2 & & & 2 \\
\hline Citrobacter diversus & + & & & 1 & 1 \\
\hline Proteus mirabilis & - & 1 & & & 1 \\
\hline Morganella morganii & + & 1 & & & 1 \\
\hline Pseudomonas aeruginosa & + & 4 & & & 4 \\
\hline Pseudomonas diminuta & - & 1 & & & 1 \\
\hline Acinetobacter calcoaceticus & - & $1(1)$ & 1 & & $2(1)$ \\
\hline Peptostreptococcus asaccharolyticus & - & $(1)$ & & & $(1)$ \\
\hline \multirow[t]{2}{*}{ Peptostreptococcus magunus } & + & 1 & & & 1 \\
\hline & 計 & $148(41)$ & $5(0)$ & $15(1)$ & $168(42)$ \\
\hline
\end{tabular}

*1 Coagulase-negative staphylococci

*2 subsp. pneumoniae 
表 2 洗浄結果一覧

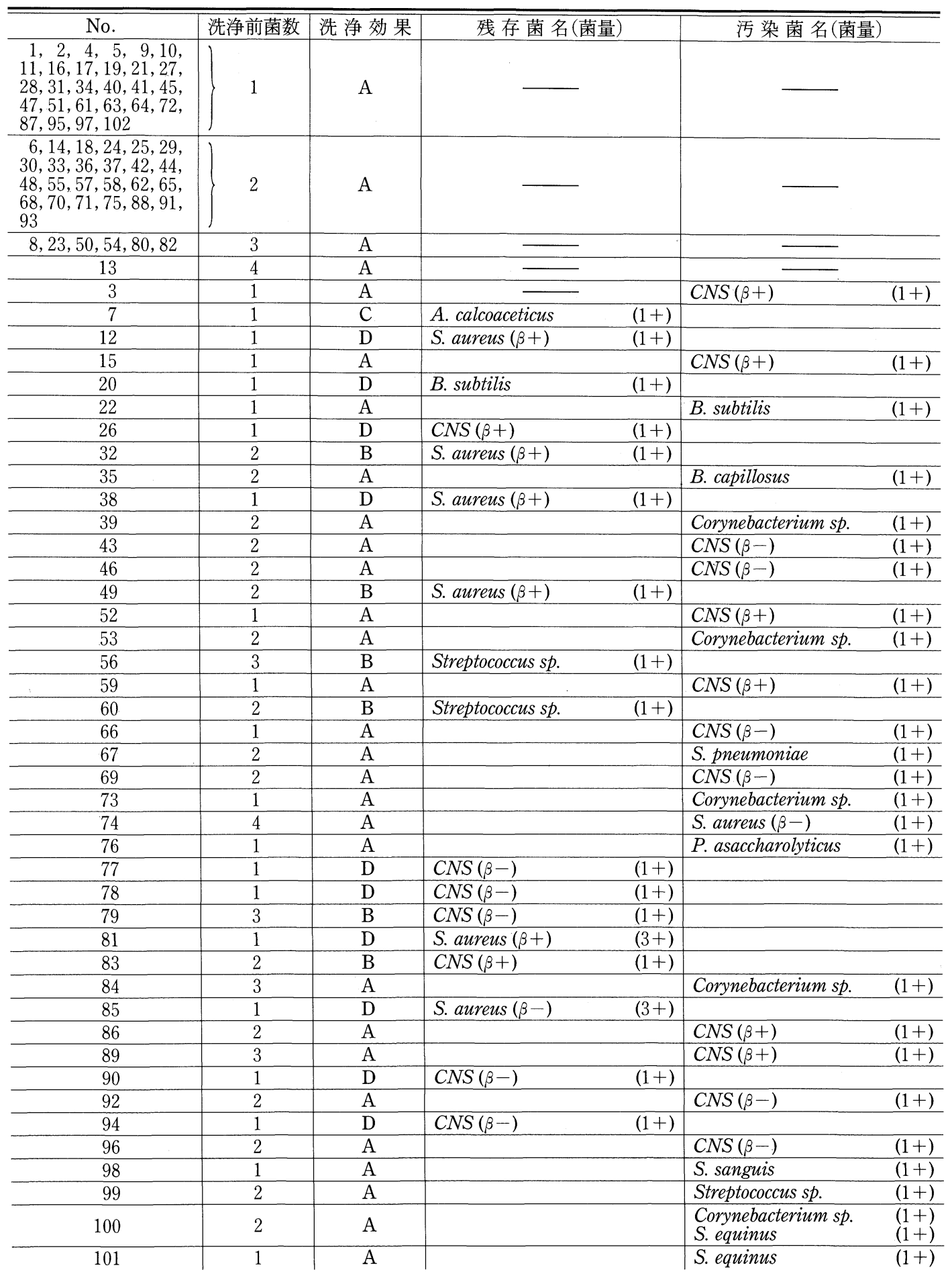
A : 菌消失
B : 菌種減
C : 菌量減
$\mathrm{D}$ : 不変 
表 3 洗浄効果

\begin{tabular}{c|r|r}
\hline \hline 洗浄効果 & 例 数 & $\%$ \\
\hline $\mathrm{A}$ & 85 & 83.3 \\
$\mathrm{~B}$ & 6 & 5.9 \\
$\mathrm{C}$ & 1 & 1.0 \\
$\mathrm{D}$ & 10 & 9.8 \\
\hline 計 & 102 & 100.0
\end{tabular}
$\mathrm{A} ：$ 菌消失
B : 菌種減
C：菌量減
$\mathrm{D} ：$ 不変

表 4 B，C，Dの残存菌 （洗浄後も残存した菌）

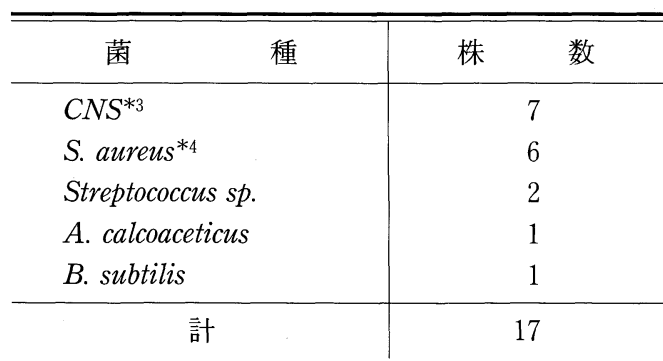

$* 3 \beta+: 2$ 株, $\beta-: 5$ 株

$* 4 \beta+: 5$ 株, $\beta-: 1$ 株

$\mathrm{B}$ : 菌種減 $\mathrm{C}$ : 菌量減 $\mathrm{D}$ : 不変

表 5 污染菌名

（洗浄前に認められず洗浄後に検出された菌名）

\begin{tabular}{l|r}
\hline \multicolumn{1}{c|}{ 菌 } & 種 \\
\hline CNS ${ }^{* 5}$ & 13 \\
Corynebacterium sp. $^{2}$ & 4 \\
S. equinus & 2 \\
S. aureus ${ }^{* 6}$ & 1 \\
S. pneumoniae & 1 \\
S. sanguis & 1 \\
P. asaccharolyticus & 1 \\
Streptococcus sp. & 1 \\
B. capillosus & 1 \\
B. subtilis & 1 \\
\hline \multicolumn{1}{c}{ 計 } & 26
\end{tabular}

*5 $\beta+： 7$ 株, $\beta$ - : 6 株

*6 $\beta+: 0$ 株, $\beta-: 1$ 株

\section{考案}

咽喉頭ファイバースコープは外来診療中に手 軽に使用でき，使用頻度が高いだけにその污染 には十分な注意が必要と思われる.今回の検討 では使用直後のファイバースュープからは， 102例の検体から168株の細菌が認められた（表 1 ). 非病原菌や，病原性の弱い菌も多く含ま れるが，S. aureus やS. pyogenes のように病原 性の強い菌や，P. aeruginosaのように臨床上 問題となる菌も認められた。

斉藤1) は喉頭, 鼻咽腔, 副鼻腔入口部の観察 後のファイバースコープ先端から認められた菌 はS. epidermidis (CNS), $\alpha$-streptococcus, Corynebacterium, Neisseria よ゙鼻咽腔の常在菌が 162 株中 134 株 $(82.7 \%)$ を占めているとし，病原 性の強い菌ではS. aureus が最も多く19株(11.7 \%)と挙げている.

当施設の結果でも，CNS が50株 (29.8\%) と 最も多く，また病原性が強いといわれる菌種と してはS. aureus が25株(14.9\%) と最も多かっ た。細菌学的分類の仕方が同一ではないため単 純には比較はできないが，斉藤の報告とほ辛同 様の傾向にあると思われた。

また斉藤の報告では，蛇口を全開とした流水

表 6 洗浄後の潜血反応

\begin{tabular}{|c|c|c|c|}
\hline No. 洗浄時間 & 3 分 & 4 分 & 5 分 \\
\hline 1 & \pm & - & \\
\hline 2 & \pm & - & \\
\hline 3 & + & - & \\
\hline 4 & - & & \\
\hline 5 & - & & \\
\hline 6 & \pm & - & \\
\hline 7 & \pm & - & \\
\hline 8 & \pm & - & \\
\hline 9 & \pm & \pm & - \\
\hline 10 & \pm & - & \\
\hline
\end{tabular}


による 1 分間の洗浄にて, 細菌の消失率は 86.1 \%としている. この数字は各菌株が洗浄により 消失したか否かを検討したものである。ファイ バースコープ先端からは 2 種以上の菌が検出さ れることもあるため, 当施設のごとく各洗浄例 ごとに，ファイバースコープ先端の細菌すべて が消失したか否かをさらに検討すると，この数 字は若干低くなるものと思われる.

当施設では 102 例のファイバースコープ洗浄 の検討を行ない, このうち85例に括いて細菌が 完全消失し，菌消失率は83.3\%であった。 これ を斉藤の報告と同様に洗浄前菌株数を母数とす ると， 89.9\%となった。

加藤 2) は flexible bronchoscope の滅菌につ いての検討に拈いて, 水道水で流しながら bronchoscope の表面を拭うことで，不完全な がら効果がみられたとしている．これらのこと からファイバースコープ使用後に打いてファイ バースコープ表面を生食を浸したガーゼなどで 軽く拭ってから洗浄器にいれることにより, 粘 液や分泌液等がある程度除去され, より高い菌 消失率すなわち高い除菌効果が得られる可能性 があると思われた。

斉藤1)の報告では流水洗浄の具体的な方法の 記載がないが, 当施設の洗浄器はファイバース ユープ先端の洗浄だけでなく，保持することな く挿入部分のすべてを洗浄することができる. 材料は水道用配管が主なものであるため安価 (計1500円足らず)であり，簡単に製作できた.

表 3 に示したよらに洗浄により検出菌が不変 であった例は $9.8 \%$ であり,これらの細菌に菌 種減の例と菌量減の例に認められた細菌を加え た残存菌は，表 4 に示したよらに17株となった。 その中で CNS が $41.2 \%$ ( 7 株), S. aureus が $35.3 \%$ ( 6 株) と多く認められた. これらの細菌 は表 1 から洗浄前にも各々 $29.8 \%$ (50株), 14.9 $\%$ (25株) と多く認められてはいるが，それ以上 に残存菌に拈ける割合は大きいと思われた。こ の結果から菌種により洗浄効果に差が出るとの 結論を出すには残存菌株数が少ないため無理が
ある.ささらに検討例数を増やすことによって結 論が得られると思われた。

表 5 から洗浄前に検出されなかった細菌が洗 浄後に認められた例は25例めり，このらち 1 例 （表 2 に括けるNo. 100 の例) は 2 種の菌株 (Corynebacterium sp. とS. equinus) が認められた. これらはファイバースコープを洗浄器から取り 出す時から先端を培地に浸すまでの間に污染さ れた可能性が大であると思われた。しかしその 他にも落下菌や洗浄管内に付着していた細菌な どによる污染も考慮の必要があると思われる. また污染による細菌の検出は洗浄前にも生じて いるはずであり, 洗浄前に検出された菌種の中 にファイバースコープ観察により先端に付着し た細菌以外の菌種も含まれていることを考慮す べきであろう．自然界に多く存在するBacillus subtilis などの検出はこのような污染によるも のである可能性が大と思われる.

今回はチャネルをもつファイバースコープの チャネル内の消毒については検討を行ってはい ない、鉗子などを用いるためのチャネル付ファ イバースコープは, 当施設ではチャネルなしの ファイバースコープに比べて使用頻度がはるか に低いため後の検討としたが，多少消毒に時間 を費やすことができるわけであるから，加藤の 報告した塩化ベンザルコニウムやブロノポール を通して洗浄する方法や, 消化器系内視鏡飞準 じて $2 \%$ グルルアルデヒドを吸引する方法31 などをとるべきであろら。

当施設で考案した流水による洗浄器は, 細菌 学的には日常の外来診療中のファイバースュー プの洗浄に使用できると考えられたが，B型肝 炎ウイルス，エイズウイルスなどは臨床的にさ らに重要な問題である。これらのウイルスに対 して有効な消毒法として $2 \%$ ルタルアルデヒ ドに約60分浸す方法4)も代表的なもののひとつ とされるようであるが，グルタルアルデヒドの 残存による腐食性咽喉頭炎の報告5) もあり, こ れを洗い流す時間や手間も必要であり，さらに 時間がかかることとなる，これでは外来診療中 
に連続して観察，洗浄を反復するのは困難であ る. $\mathrm{Hb}$ 抗原陽性などの汪か, あらかじめ危険 性が考光られる場合はもちろん上記のよらな充 分時間をかけての消毒をするべきであるが，そ らでない場合でも短時間でできる可能なかぎり のこれらのウイルスに対する消毒を行っでく ベきであろら。

今回の検討ではこれらのウイルスの洗浄によ る消毒効果の参考としてファイバースコープ先 端の潜血反応検査を行なった. Bond ら ${ }^{6)}$ はフ ァイバースコープによる B 型肝炎ウイルス感染 の危険性の検討のなかで, 潜血反応が $\mathrm{Hbs}$ 抗 原検出の目安となるとしており，また神木ら3) は内視鏡消毒の基準を提案し，そのひとつとし て洗浄した液について潜血反応が陰性であるこ とをあげている。これらの報告からもウイルス の消毒効果の判定に潜血反応を応用することは 簡便かつ適当と考光た。

鼻出血患者に用いたファイバースコープは， 5 分以内の洗浄で 10 例全例が潜血反応陰性とな っているので, Bond ら6)の報告によればこれ らの患者の血液が Hbs 抗原陽性であっても洗 浄後は感染の危険性はないといらことになる. 今回の細菌学的な検討はすべて 3 分間の洗浄で 行ったが，潜血反応陰性となるためには10例中 2 例は 3 分であり， 7 例が 4 分であり， 1 例が 5 分であったことから，5分間の洗浄が好まし いといえる. しかし, 肉眼的に認められるファ イバースコープに付着した血液を, 生理的食塩 水を浸したガーゼなどで軽く拭ってから洗浄す ることにより，洗浄時間を短縮できることも考 えられる、今回は10例のみの検討であるのでさ らに例数を増やし, 時間的検討をも行なら必要 があると思われる。

当施設の流水によるファイバースコープ洗浄 器は, 外来診療中の手軽でかつ安全な洗浄法と して感染症学的にも効果が期待されると思われ たが，さらに効果を確実なものとするため検討 を重ねるつもりである.

\section{結語}

1. 外来診療中に手軽に使用できる, 流水に よる咽喉頭ファイバースコープ洗浄器を考案し, 洗浄効果を検討した.

2. 日常外来診療に打ける咽喉頭ファイバー スコープ検査後, ファイバースコープ先端から 平均1.65種の細菌が検出された.

3 . 洗浄器の使用により, 洗浄前に検出され た細菌が消失した例は102例中85例(83.3\%)， 菌種が減少したものは 6 例(5.9\%), 菌量が減 少した例は 1 例 $(1.0 \%)$, 検出菌種, 菌量に変 化が無く, 洗浄効果が認められなかったものは 10例(9.8\%)であった。

4. 洗浄前に認められなかった菌種が，洗浄 後に検出された例(污染)は, 102例中25例(24.5 \%)認められ，菌量はいずれも少量であり， CNS や, Corynebacterium など病原性の低い菌 種が多かった。

5. 鼻出血患者の鼻内を観察したファイバー スコープは 5 分間の洗浄により10例全例が潜血 反応陰性となった。

6. 当施設で考案した流水によるファイバー スコープ洗浄器の使用は, 連続してファイバー スコープ検査を行なら場合の洗浄法として効果 的と思われた。

稿を終わるにあたり御校閲戴いた順天堂大学市川 銀一郎教授飞深甚なる謝意を表します。また㸸切な る御助言を戴いた東京総合臨床センター研究部の出 口浩一先生, 研究作業を手伝って戴いた江東病院耳 鼻科外来の看護婦の方々飞深謝いたします。

\section{参考文献}

1）斎藤成明：日常臨床に使用するファイバース コープの消毒について. JOHNS 1:939〜942, 1985.

2）加藤秀雄：フレキシブルファイバーブロンコス コープを引き続いて頻回使用する際に行う器具 減菌方法に対する実験的研究. 日気食会報 24： 259 267, 1974.

3）神木昭雄, 奥田 茂: 内視鏡の消毒に関する研 究. Gastroenterological Endoscopy 22 : 663〜 
675, 1980.

4）加藤秀雄 : ファイバースコープの隇菌・消毒法. 日気食会報 $37: 422 \sim 423,1986$.

5）小林仁和, 宮国泰明, 涌谷忠雄 : 殺菌消毒剂 (STERIHYDE) そよる腐食性咽喉頭炎。耳鼻 $28: 1121 \sim 1125,1982$.

6) Bond WW and Moncada RE : Viral hepatitis B infection risk in flexible fiberoptic endoscopy. Gastrointest Endosc 24 : 225 230, 1978.

$$
\left.\begin{array}{l}
\text { 原稿受付: 平成 } 3 \text { 年 } 3 \text { 月 } 12 \text { 日 } \\
\text { 原稿採択: : 平成 } 3 \text { 年 } 4 \text { 月 } 4 \text { 日 } \\
\text { 別刷請求先: 板橋隆嗣 } \\
\text { † } 136 \text { 東京都江東区大島 } 6-8-5 \\
\text { 江東病院耳鼻咽喉科 }
\end{array}\right)
$$

